\title{
Editor's Introduction: Nurturing New Historical Voices
}

\author{
Lawrence T. Nichols ${ }^{1}$
}

Accepted: 21 June 2021/ Published online: 5 July 2021

(C) The Author(s), under exclusive licence to Springer Science+Business Media, LLC, part of Springer Nature 2021

In this issue we continue an effort that began about eight years ago to nurture "new voices" in the history of sociology. At that time, pursuant to a suggestion by Charles Camic of our editorial board, I began working with Michael Bare and Laura Ford, both then doctoral students, to organize an issue on "junior historians" along the lines of the "junior theorists" initiative of the American Sociological Association. The result was a thematic set of papers covering a wide range of historical topics that appeared as volume 46, number 2 (June 2015).

The present issue arises largely from a symposium organized by the History of Sociology section of ASA that was held online in August 2020. Laura Ford (now a professor at Bard College) and Gillian Niebrugge-Brantley, chair of the HOS section, describe this event in their introductory essay, and so I will not repeat the details here. I would like to express my thanks and appreciation to professors Ford and NiebruggeBrantley, as well as to their colleagues on the committee that worked with them to arrange the symposium.

Some of the symposium presentations did not develop into submissions to the journal. Also, a few submissions were undergoing final revisions at the point when we needed to go to press. These will appear in a subsequent issue. Here we offer eight papers along with the introduction by professors Ford and Niebrugge-Brantley.

Stefan Bargheer illumines some surprising connections between C. Wright Mills and two of the main targets of Mills's criticisms in The Sociological Imagination, namely Talcott Parsons (accused of writing inscrutable "grand theory") and Paul Lazarfeld (indicted for focusing on relatively trivial grant-funded empirical findings). A unifying thread, according to Bargheer, is the use that each made of "paper tools," especially two-by-two tables that both learned from statistician and social psychologist Samuel Stouffer. Most significantly, Mills, Parsons and Lazarsfeld all employed such tables not merely to display data but also to generate theoretical possibilities for further exploration. Indeed, this was a basic feature of the "intellectual craft" that Mills advocated in Sociological Imagination.

Lawrence T. Nichols

ltnichols@ retiree.wvu.edu

1 West Virginia University, Morgantown, WV, USA 
Angela Fillingim and Zawadi Rucks-Ahidiana offer a thoughtful critique of the teaching of the history of sociological theory. In particular, the authors are concerned that typical history of theory courses may tend, however unintentionally, to reproduce earlier patterns of exclusion. They therefore argue for an alternative curriculum and pedagogy organized around core issues, such as the rise of capitalism and the presentation of self in everyday life, which the authors believe might better connect with the experiences and concerns of today's diverse students.

Alec McGail contributes the most ambitious empirical essay in this issue, based on an enormous data base the author constructed of citations of more than ninety-three thousand articles from 73 journals that appeared between 1930 and 2020. While this can be used for many research purposes, McGail draws on it to reveal ideas and works that have been largely forgotten. The author argues that this analysis allows us to see topical and epistemological shifts, as well as founder selection, reputation entrepreneurship, and fluctuations of what is "intellectually unspeakable."

Ben Merriman examines annual reports from editors of ASA-sponsored journals over a period of nearly seventy years in order to trace the evolution of double-blind peer review. The author shows that the elements of now standard practices, such as ad hoc review and desk rejection, developed separately over a number of decades. Merriman concludes that the process is best understood not in terms of intellectual considerations, but rather in terms of efforts by editors to make the best use of scarce resources while preserving an open submission policy favorable to authors.

Ryan Parsons offers a thoughtful discussion of the concept of "caste" that began to be applied in U.S. social anthropology and sociology in the 1930s, largely via the works of W. Lloyd Warner and a circle of collaborators including Allison Davis, John Dollard and Burleigh Gardner. After surveying earlier treatments in the professional literature, Parsons makes a case for an alternative approach that views caste in terms of "racialized economic performance."

Francesco Ranci traces the rise of Erving Goffman from the margins of a Russian Jewish immigrant community in Canada to the center of U.S. sociology. The author argues that excessive emphasis on seemingly "enigmatic" or "outrageous" aspects of Goffman's personality has tended to detract from appreciation of Goffman's theoretical writings. Ranci suggests that the ideas of "the stranger" and of "moral alchemy" might help us better understand the mixture of celebration and neglect that has marked the response to Goffman in the field.

Hannah Waight provides a highly sophisticated discussion of what the author calls John Dewey's "lost vision" for social science. After documenting a recent revival of interest in Dewey's works via citation analysis, Waight points to a continuing tension between what Dewey actually said and personally believed and the ways in which portions of Dewey's thought have been used in recent professional literature. The author concludes with the hope that a recovery of Dewey's original vision might benefit sociology, especially in terms of a better understanding of the relationship between the world we study and sociological theory.

Taylor Page Winfield offers a methodology that might prove useful in historical research on the development of sociology. The author argues that focusing on the "thought-models" of particular thinkers has the potential to illumine the influence of particular cultural currents that shape the response to historical figures, resulting at times in their celebration and at other times in their marginalization. Winfield focuses in 
particular on South African author and feminist activist Olive Schreiner as an example of how a "thought-model" analysis might be accomplished. In this case, according to the author, Protestant Christian, Enlightenment, and socialist activist-scholar models combined to produce a distinctive social theory.

As I commented at the conclusion of the HOS symposium last August, becoming a "new voice in the history of sociology" is often quite difficult, as many factors combine to work against it. During graduate school, students are required to focus rather narrowly on a research topic for a dissertation or a set of related papers, and this usually means an issue in some substantive area such as gender or criminology. Such research is an important credential in attaining an initial academic job. Meanwhile, sociology departments do not generally design positions for historians of the discipline, but rather for specialists in the substantive areas emphasized in their programs. For those fortunate enough to acquire a tenure-track position, the next several years are often a time of much pressure to publish, again, in the area of specialization during doctoral studies. There may be less pressure at teaching-oriented schools, but in such cases teaching loads are generally heavier and there are fewer resources to support research. Thus, it might be only after one has attained promotion with tenure that one feels there is the opportunity to pursue historical research.

Even with such increased freedom, aspiring historians face serious challenges. In many universities, their efforts might not be highly valued by department chairs and review committees or higher administrators. Indeed, tenured faculty still experience a great deal of pressure to carry out grant-funded research in a substantive area, in order to remain in good standing or to advance toward a "full" professorship. The situation may be better in more teaching-oriented schools, though, again, faculty there must deal with heavy teaching loads and the scarcity of resources to support research. In some cases, historical work might be tolerated as a sort of "hobby" but not valued on a par with other, especially funded research. On top of it all, there is the problem of a relative scarcity of publication outlets for historical work.

My own experience was rather mixed. I certainly did not enter graduate school with any idea of becoming a "new voice" in the history of sociology. During M.A. studies, a two-semester course on European and American sociological theories awakened an interest in the history of the discipline, which had hardly been touched on during undergraduate coursework. In the process, I became deeply interested in the works of Pitirim Sorokin, especially on macro-level cultural analysis and on altruism and a sociology of love. I began to wonder why Sorokin seemed to be a relatively forgotten figure. This highly impractical fascination led to a low-budget trip by bus to Saskatoon, Canada in order to examine Sorokin papers there, and then to repeated visits over many years to the Harvard University Archives. Meanwhile, after teaching at a number of Boston-area schools, I was hired by West Virginia University to help build up the areas of criminology and the sociology of business. Fortunately, WVU was willing to count my historical publications, along with my other work in criminology, corporate social responsibility and social problems theory, for credit toward promotion with tenure and subsequently for promotion to professor. Along the way, I met many wonderful people, some of whom have become long-term friends. Like me, many were driven by some strong personal interest in a historical individual or topic, and they "worked around" the other demands of their academic appointments. There was a sort of shared sense of adventure, and a joy in the historical quest - qualities not always found in the routine of 
teaching or grinding out publications in a specialty area under the pressure of grantrelated deadlines. To top it off, it was my impractical historical quest that led to correspondence with the late Irving Louis Horowitz and to the invitation to apply for the editorship of this journal.

Perhaps the "new voices" featured in this issue will have their own historical adventures, and I wish them every success. Above all, I hope that whatever historical work they undertake will be motivated by a sense of what has been good in sociology, as well as the good that the field has to offer to the world. Critique has its place. But there should also be joy in exercising the sociological imagination as a "working historian."

Publisher's Note Springer Nature remains neutral with regard to jurisdictional claims in published maps and institutional affiliations. 